\title{
The Effect of FDI in the Albania Economy
}

Doi:10.5901/ajis.2014.v3n3p421

Alket Kullolli

\section{Abstract}

FDI has been a major development of the last decades helping world economic development. It is known that the growth in FDI (Foreign Direct Investment) is increasing at the global scenario. We see this increase in the last decade, especially in the developing countries like Albania. They are important for developing countries, in transition and developed countries. This paper will investigate the effect of the economic indicators on the FDI (Foreign Direct Investment) in Albania. For the research Methodology the data's of FDI, GDP Growth, Inflation from 1992 - 2012 have been use for the purpose of studies. To check the normalcy of the data's various statistical tools are used as: Mean, Standard Derivation, Variance and Kurtosis. Regression and Correlation analysis have been used to study the relationship dependency of these variables. The findings show that there is a visible effect of the economic indicators of Albania on the FDI (Foreign Direct Investment). The results of the correlation and regression analysis will be illustrated by graphs where they show the significant impact of the economic indicators of the FDI. This study investigates the impact of the economic indicators of Albania on the FDI with the use of the current statistics.

\section{Introduction of the Study}

In the last decade, in Albania there is a big interest from FDI. This is because Albania is a developing country and has lot of possibilities for new ideas and new businesses. After the communism time Albania was a country which had not knowledge about the foreign products This exceptional augmentation of global FDI makes FDI a vital and imperative factor of improvement policy in both developed and developing countries. Albania comes among those countries which attracts the FDI inflows. The FDI increase the economic activity and expands the market sizes by offering great opportunities for the Albanian population, employment level and have strong effect in the development of the country like Albania. Albania offers great opportunities for foreign investors to reap a good success and good profit from their businesses.

After a plodding rise from 1991 till the end 1999 inflows increased rapidly thereafter. From an average of 51.4 million of US $\$$ and the effect of this we will see shown by graph in the GDP of the Albania. From 2000-2003 we see a slightly higher average of 163.5 million of US \$. Than from 2004 we have an increment of the incomes from FDI.

After visa liberation which was in the end of the December of 2010 we have a slightly lower decrement of the income from the FDI in 2011and 2012 and this will have an effect of the Albanian GDP. This effect will be illustrated by graph. This was because a lot of Albanian went in other countries to their families because as we know the Albania population mostly $30 \%$ emigrants in other countries. This affect in the purchasing power because less peoples buys less and when they were here we had an incomes from remittances. So there was less money in these 2 years and less purchasing power.

\section{The Graphs Supports these Facts}

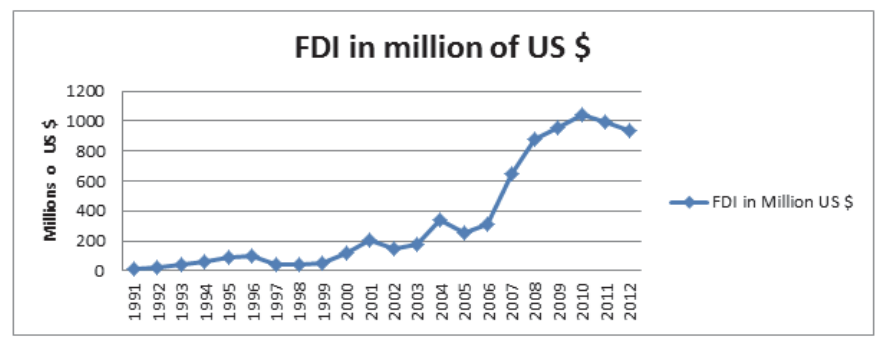



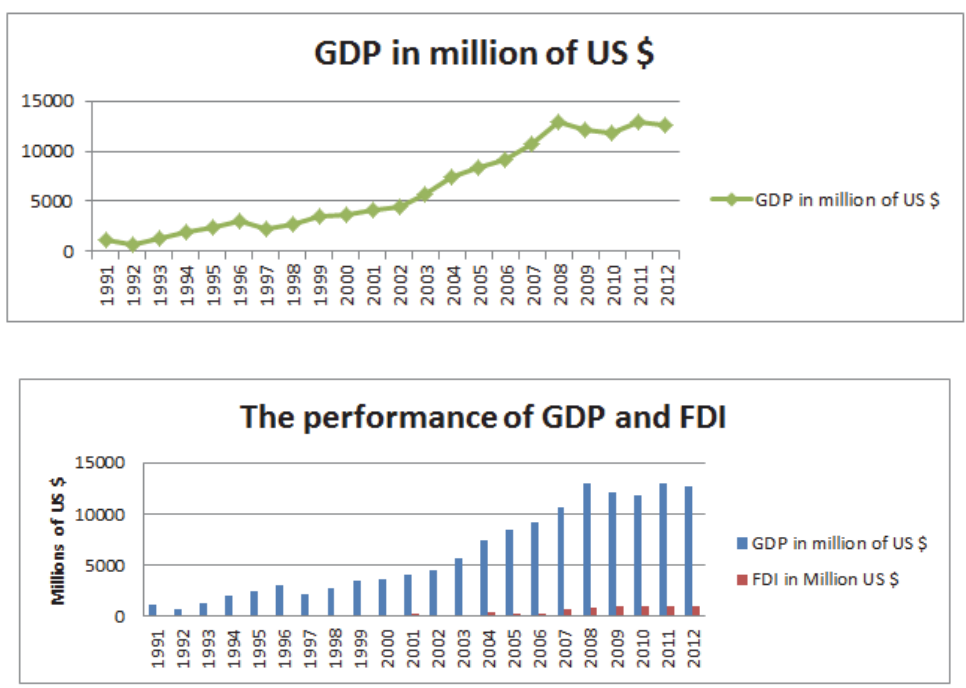

The graphs show a big jump in the FDI in Albania after 2001.

In 2010 we have the peak of the FDI in Albania which is 1043 million of US \$.

Albania economy attracts the FDI because of the growth in the GDP, attractive exchange rates, controlled inflation rate, geographic position etc. The Albanian geographic position is favorable for every kind of FDI because it has all condition for being a healthy and successful investment. The current study will evaluate the effect of the economic indicator on FDI.

\section{Objectives of the Study}

1. To find out the effect of FDI on the economic indicators.

2. How does the FDI effects in the GDP

3. The benefits of a country and a firm which is investing in this country

From a country perspective:

We have the Renaissance of the market system.

We have the Globalization of the economic system.

We have the Enhanced mobility of wealth creating assets.

We have the Increasing number of countries approaching the take-off stage in development. economies.

We have the Convergence of the economic structure among developing countries and some new industrializing

We have the Changing the criteria which governments evaluate FDI.

Better appreciation by the governments of the costs and benefits of FDI.

From a firm's perspectives:

Increasing need to exploit global markets

Competitive pressure to procure inputs

Regional integration has prompted more efficiency-seeking investments.

Growing case of trans-border communications and reduce transport costs.

It heightened oligopolistic competition among leading firms.

It opens up new territorial opportunities for FDI.

Need to tap into foreign sources of the technology and organizational capabilities and exploit economies of agglomeration.

We can have new incentives to conclude alliance with foreign firms.

We can see changes in significance of particular location costs and benefits.

Need to better balance the advantages of globalization with those of localization 


\section{Review}

A lot of scholars and economists studied the FDI and FDI-s effects on the different countries economy.

- Balasubramanyam et al. (1996) studied the effect of the FDI on economic growth of the country.

- Bornstein in 1998 investigated the variation of FDI among different countries

- Bangoa and Sanchez-Robles in 2003 studied and explored the correlation of FDI with economic growth, economic stability, liberalized markets and human capital.

- In this year Choe analyzed casual relationships between economic growth and FDI.

- In 2004 Alfaro examined the links among FDI, financial markets and economic growth.

In this year John Andreas evaluated the potential of FDI inflows to affect host country economic growth.

In 2005 Ching studied the impact of exchange rate movements on FDI.

In this year Mavrotas investigated the effect of FDI on different developing countries.

In 2006 Bayie studied the relationship of FDI and GDP growth.

In this year Miguel Ramirez evaluates the impact of FDI on labor productivity function.

Even the Economist revealed a number of facts related to FDI, the researchers find out the effects of the FDI on the economic indicators. Not many studies have been concentrated on the Albanian to evaluate these effects.

The present study will investigate the effect of the FDI in the Albanian GDP.

\section{Research Methodology}

The present study will investigate the relation of FDI and GDP of Albania.

The Albania data of GDP and FDI from 1991-1992 to 2011-2012 has been used to perform the analysis. Following tools and following programs have been used for the purpose of this paper.

The mean is a particular informative measure of the central tendency of the variable if its reported along with its confidence intervals

Sometimes we get interested in statistics from our sample only to extent to which they can infer information about the population.

The confidence intervals for the mean give us a range of values around the mean where we except the "true" mean is located.

\section{The Relation between Foreign Direct Investments and Gross Domestic Product}

The two models conducted are:

$$
\begin{aligned}
& G D P_{t}=C_{t}+\beta_{0} F D I_{t}+u_{t} \\
& G D P_{t}=C_{t}+\beta_{0} F D I_{t}+\beta_{1} F D I_{t-1}+u_{t}
\end{aligned}
$$

Where:

- $\mathrm{GDP}_{\mathrm{t}}$ in both models is the dependent variable and represent the Gross Domestic Product annual changes in percentage at time $t$.

- FDlt and FDlt-1 represent annual changes in percentage respectively at time $t$ and $t-1$

- $C_{t}$ represents the intercept which is equal to $\mathrm{GDP}_{\mathrm{t}}$ if all the independent variables equals zero.

- $\beta_{0}$ and $\beta_{1}$ are the slopes of their respective variable.

- $u_{t}$ represents the estimated error.

The Eview program the results for the no lag model are shown in table 3 and for the one lag model in table 4 .

Accordingly, the estimated models are.

$$
\begin{aligned}
& G D P_{t}=0.099+0.014 F D I_{t} \\
& G D P_{t}=0.071+0.202 F D I_{t}+0.112 F D I_{t-1}
\end{aligned}
$$




\section{Table 1}

Dependent Variable: GDP

Method: Least Squares

Date: 06/16/14 Time: 20:45

Sample: 19922012

Included observations: 21

Variable Coefficient Std. Error t-Statistic Prob.

\begin{tabular}{|c|c|c|c|c|}
\hline $\begin{array}{c}\text { FDI } \\
\text { C }\end{array}$ & $\begin{array}{l}0.143239 \\
0.098861\end{array}$ & $\begin{array}{l}0.102202 \\
0.063113\end{array}$ & $\begin{array}{l}1.401532 \\
1.566397\end{array}$ & $\begin{array}{l}0.1772 \\
0.1338\end{array}$ \\
\hline R-squared & 0.093697 & Mean dependent var & & 0.147795 \\
\hline Adjusted R-squared & 0.045997 & S.D. dependent var & & 0.246674 \\
\hline S.E. of regression & 0.240934 & Akaike info criterion & & 0.081807 \\
\hline Sum squared resid & 1.102937 & Schwarz criterion & & 0.181286 \\
\hline Log likelihood & 1.141024 & Hannan-Quinn criter. & & 0.103397 \\
\hline F-statistic & 1.964291 & Durbin-Watson stat & & 1.778156 \\
\hline
\end{tabular}

According the results in table 10, 1 percent increase in FDI increases GDP by 0.14 percent. Yet, the dependent variable is statistically insignificant in predicting the model ( $p$-value greater than $0.05,1,5$ and 10). Also R-square is very low. (Optimal benchmark $=60 \%$ )

Table 2

Dependent Variable: GDP

Method: Least Squares

Date: 06/16/14 Time: $20: 46$

Sample (adjusted): 19932012

Included observations: 20 after adjustments Variable $\quad$ Coefficient $\quad$ Std. Error t-Statistic $\quad$ Prob.

\begin{tabular}{ccccc}
\hline \hline FDI & 0.202137 & 0.085106 & 2.375134 & 0.0296 \\
FDI(-1) & 0.112939 & 0.082819 & 1.363676 & 0.1905 \\
C & 0.070776 & 0.054876 & 1.289735 & 0.2144
\end{tabular}

\begin{tabular}{llll}
\hline \hline R-squared & 0.354249 & Mean dependent var & 0.174030 \\
Adjusted R-squared & 0.278278 & S.D. dependent var & 0.220990 \\
S.E. of regression & 0.187740 & Akaike info criterion & -0.370036 \\
Sum squared resid & 0.599188 & Schwarz criterion & -0.220676 \\
Log likelihood & 6.700358 & Hannan-Quinn criter. & -0.340879 \\
F-statistic & 4.662962 & Durbin-Watson stat & 1.402809 \\
Prob(F-statistic) & 0.024297 & &
\end{tabular}

According to the results in table 10, FDI of the current year is statistically significant in predicting the model at 3percent significance level ( $P$-value $=0.02$ ). It has a positive impact on GDP when 1 percent increases in FDI, increases GDP by 0.20 percent. Also, the results indicate that an increase of FDI will have a positive impact of the coming year by 0.11 percent if increase only by $1 \%$. Yet this variable is statistically insignificant in predicting the model. Moreover, Prop(Fstatistic) $=0.024$ indicating that both FDI at $t$ time and $t-1$ time are jointly statistically significant at 2.5 percent (or higher) significance level. However, the R-square is low when only 35 percent of the data explain the model. 


\section{Unit Root Test}

Moreover, FDI series does not have a unit root at a significance level equal of higher than 2 percent. Also, after testing the first difference of FDI for unit root, has resulted that D_FDI has not a unit root thus this series is non-stationary.

Table 3: ADF test FDI

Null Hypothesis: FDI has a unit root

Exogenous: Constant

Lag Length: 0 (Automatic - based on SIC, maxlag=0)

t-Statistic Prob.*

\begin{tabular}{crcc}
\hline \hline \multicolumn{2}{c}{ Augmented Dickey-Fuller test statistic } & -3.529728 & 0.0179 \\
\hline Test critical values: & 1\% level & -3.808546 & \\
& 5\% level & -3.020686 & \\
& $10 \%$ level & -2.650413
\end{tabular}

*MacKinnon (1996) one-sided p-values.

Table 4: ADF test FDI at 1st difference

Null Hypothesis: D(FDI__CHNG) has a unit root

Exogenous: Constant

Lag Length: 0 (Automatic - based on SIC, maxlag=0)

\begin{tabular}{|c|c|c|c|}
\hline & & t-Statistic & Prob.* \\
\hline \multicolumn{2}{|c|}{ Augmented Dickey-Fuller test statistic } & -5.354696 & 0.0004 \\
\hline Test critical values: & $\begin{array}{c}1 \% \text { level } \\
5 \% \text { level } \\
10 \% \text { level }\end{array}$ & $\begin{array}{l}-3.831511 \\
-3.029970 \\
-2.655194\end{array}$ & \\
\hline
\end{tabular}

Table 5: PP Test FDI (level)

Null Hypothesis: FDI has a unit root

Exogenous: Constant

Bandwidth: 10 (Newey-West automatic) using Bartlett kernel

\begin{tabular}{|c|c|c|c|}
\hline & & Adj. t-Stat & Prob.* \\
\hline \multicolumn{2}{|c|}{ Phillips-Perron test statistic } & -3.877800 & 0.0086 \\
\hline Test critical values: & $\begin{array}{c}1 \% \text { level } \\
5 \% \text { level } \\
10 \% \text { level }\end{array}$ & $\begin{array}{l}-3.808546 \\
-3.020686 \\
-2.650413\end{array}$ & \\
\hline
\end{tabular}

*MacKinnon (1996) one-sided p-values.

\section{Findings and Analyses}

This part of the study reveals the findings and analysis after evaluating the data of GDP and the data of FDI from the period of 1991-1992 to 2011-2012.

The table below shows the result of the descriptive statistics. These tests have been performed to check the normality of the data. 


\section{Conclusion}

The study shows and proofs that there is a quite significant impact of the FDI on the GDP.

The findings shows that the attractive position and favorite taxes are attractive for the a huge number of FDI investing in Albania.

From the study we see that this huge attractive number of FDI which want to invest in Albania brings huge profits for the Albanian economy (it helps to decrease the number of unemployment peoples which is one of the biggest problem now days)

As we can see from the tables above the average FDI in Albania during this period is 339.87 million Of US $\$$ and the average of the GDP during this period is 6135.1 million of US \$.

So from this data we can see that there is a considerable effect of the FDI in the GDP of Albania.

\section{References}

(BoA), 3. C. (2013). Economic Indicators. Albania: Central bank of Albania (BoA).

n.d.). FDI and Growth: What causes what?. World Institute for Development Economic Research of the United Nations.

A. (n.d.). The effect of the FDI inflows on Host Country Economic Growth. The effect of the FDI inflows on Host Country Economic Growth.

Bornstein. (n.d.). how does FDI effect economic growth. Journal of the international economics , - pp. (115-135).

Choe. (n.d.). Do FDI GDI (Gross Domestic Investment) promote economic growth? . Review of the development economics, No.7 pp. (44-57).

Balasubramanyam, 4. s. (n.d.). Foreign Direct Investment and growth in EP and IS countries. Economic journal , 92-105. data's, 2. B. (2013). Statistics and data's. World Bank .

indicators, W. d. (n.d.). World Development Indicators. World Development Indicators.

Mundi, 1. E. (2013). Albanian Economy Profile. Mundi.

Ramirez, 6. D. (n.d.). is FDI Beneficial for Mexico? A empirical analyses “World Development”, vol 34, No 5, pp. (802-817).

\section{Appendixes: FDI and GDP Series Taken at Yearly Changes}

\section{T5: ADF test FDI (level)}

Null Hypothesis: FD CHNG has a unit root

Exogenous: Constant

Lag Length: 0 (Automatic - based on SIC, maxlag=0)

\begin{tabular}{|c|c|c|c|}
\hline & & t-Statistic & Prob.* \\
\hline \multicolumn{2}{|c|}{ Augmented Dickey-Fuller test statistic } & -3.529728 & 0.0179 \\
\hline \multirow[t]{3}{*}{ Test critical values: } & 1\% level & -3.808546 & \\
\hline & $5 \%$ level & -3.020686 & \\
\hline & $10 \%$ level & -2.650413 & \\
\hline
\end{tabular}

*MacKinnon (1996) one-sided p-values.

Augmented Dickey-Fuller Test Equation

Dependent Variable: D(FDI CHNG)

Method: Least Squares

Date: 06/16/14 Time: 20:40

Sample (adjusted): 19932012

Included observations: 20 after adjustments

\begin{tabular}{llllc}
\hline \multicolumn{1}{c}{ Variable } & Coefficient & Std. Error & t-Statistic & Prob. \\
\hline \hline FDI_CHNG(-1) & -0.790661 & 0.224001 & -3.529728 & 0.0024 \\
& 0.232988 & 0.141713 & 1.644084 & 0.1175 \\
\hline \hline R-squared & 0.409041 & Mean dependent var & & -0.053010 \\
Adjusted R-squared & 0.376210 & S.D. dependent var & & 0.658329 \\
S.E. of regression & 0.519951 & Akaike info criterion & & 1.624474 \\
Sum squared resid & 4.866278 & Schwarz criterion & 1.724047 \\
Log likelihood & -14.24474 & Hannan-Quinn criter. & 1.643912 \\
F-statistic & 12.45898 & Durbin-Watson stat & & 1.936256 \\
Prob(F-statistic) & 0.002393 & & \\
\hline
\end{tabular}

FDI has a not test at level at $0.05 \% \rightarrow$ stationary. FDI has not a unit root at level at $1 \% \rightarrow$ non-stationary 


\section{T6: ADF test FDI at $1^{\text {st }}$ difference}

Null Hypothesis: D(FDI

Exogenous: Constant

CHNG) has a unit root

Lag Length: 0 (Automatic - based on SIC, maxlag=0)

\begin{tabular}{|c|c|c|c|}
\hline & & t-Statistic & Prob.* \\
\hline \multicolumn{2}{|c|}{ Augmented Dickey-Fuller test statistic } & -5.354696 & 0.0004 \\
\hline \multirow[t]{3}{*}{ Test critical values: } & $1 \%$ level & -3.831511 & \\
\hline & $5 \%$ level & -3.029970 & \\
\hline & $10 \%$ level & -2.655194 & \\
\hline
\end{tabular}

*MacKinnon (1996) one-sided p-values.

Warning: Probabilities and critical values calculated for 20 observations

and may not be accurate for a sample size of 19

Augmented Dickey-Fuller Test Equation

Dependent Variable: D(FDI_CHNG,2)

Method: Least Squares

Date: 06/16/14 Time: 20:42

Sample (adjusted): 19942012

Included observations: 19 after adjustments

\begin{tabular}{|c|c|c|c|c|}
\hline Variable & Coefficient & Std. Error & t-Statistic & Prob. \\
\hline $\mathrm{D}\left(\mathrm{FDI} \_\mathrm{CHNG}(-1)\right)$ & -1.249765 & 0.233396 & -5.354696 & 0.0001 \\
\hline $\mathrm{C}$ & -0.082683 & 0.154172 & -0.536303 & 0.5987 \\
\hline R-squared & 0.627787 & \multicolumn{2}{|c|}{ Mean dependent var } & -0.014005 \\
\hline Adjusted R-squared & 0.605892 & \multicolumn{2}{|c|}{ S.D. dependent var } & 1.066763 \\
\hline S.E. of regression & 0.669693 & \multicolumn{2}{|c|}{ Akaike info criterion } & 2.135305 \\
\hline Sum squared resid & 7.624299 & \multicolumn{2}{|c|}{ Schwarz criterion } & 2.234719 \\
\hline Log likelihood & -18.28540 & \multicolumn{2}{|c|}{ Hannan-Quinn criter. } & 2.152130 \\
\hline F-statistic & 28.67276 & \multirow{2}{*}{\multicolumn{2}{|c|}{ Durbin-Watson stat }} & 2.124073 \\
\hline Prob(F-statistic) & 0.000053 & & & \\
\hline
\end{tabular}

FDI has not a unit root at $1^{\text {st }}$ difference $\rightarrow$ non-stationary

\section{T7: PP test FDI (level)}

Null Hypothesis: FDI has a unit root

Exogenous: Constant

Bandwidth: 10 (Newey-West automatic) using Bartlett kernel

\begin{tabular}{|c|c|c|c|c|}
\hline & & & Adj. t-Stat & Prob.* $^{*}$ \\
\hline \multicolumn{3}{|c|}{$\begin{array}{l}\text { Phillips-Perron test statistic } \\
\end{array}$} & -3.877800 & 0.0086 \\
\hline \multirow[t]{3}{*}{ Test critical values: } & $1 \%$ level & & -3.808546 & \\
\hline & $5 \%$ level & & -3.020686 & \\
\hline & $10 \%$ level & & -2.650413 & \\
\hline \multicolumn{5}{|c|}{ *MacKinnon (1996) one-sided p-values. } \\
\hline \multicolumn{3}{|c|}{ Residual variance (no correction) } & & 0.243314 \\
\hline \multicolumn{3}{|c|}{ HAC corrected variance (Bartlett kernel) } & & 0.060419 \\
\hline \multicolumn{5}{|c|}{ Phillips-Perron Test Equation } \\
\hline \multicolumn{5}{|l|}{ Dependent Variable: D(FDI) } \\
\hline \multicolumn{5}{|l|}{ Method: Least Squares } \\
\hline \multicolumn{5}{|l|}{ Date: 06/16/14 Time: $20: 55$} \\
\hline \multicolumn{5}{|c|}{ Sample (adjusted): 19932012} \\
\hline \multicolumn{5}{|c|}{ Included observations: 20 after adjustments } \\
\hline $\begin{array}{cc}\text { Variable } \\
\end{array}$ & Coefficient & Std. Error & t-Statistic & Prob. \\
\hline FDI(-1) & -0.790661 & 0.224001 & -3.529728 & 0.0024 \\
\hline C & 0.232988 & 0.141713 & 1.644084 & 0.1175 \\
\hline R-squared & 0.409041 & Mean dependent var & & -0.053010 \\
\hline Adjusted R-squared & 0.376210 & S.D. dependent var & & 0.658329 \\
\hline S.E. of regression & 0.519951 & Akaike info criterion & & 1.624474 \\
\hline Sum squared resid & 4.866278 & Schwarz criterion & & 1.724047 \\
\hline Log likelihood & -14.24474 & Hannan-Quinn criter. & & 1.643912 \\
\hline F-statistic & 12.45898 & Durbin-Watson stat & & 1.936256 \\
\hline Prob(F-statistic) & 0.002393 & & & \\
\hline
\end{tabular}

